\title{
HUBUNGAN GAYA KEPEMIMPINAN GURU DALAM MENINGKATKAN MOTIVASI BELAJAR PENJAS PADA SISWA SEKOLAH DASAR
}

\author{
Nanang Mulyana \\ STKIP Muhammadiyah Kuningan \\ email : nmulyana722@gmail.com
}

\begin{abstract}
Guru sebagai pembimbing dan motivator sangat berperan untuk kemajuan pendidikan, sikap memberi dan mendahuluan kepentingan siswa/umum menjadi teladan dalam perilaku akan menjadikan panutan pengikut-pengikutnya atau siswasiswi itu dengan sendirinya. Masalah dalam penelitian ini adalah hubungan gaya kepemimpinan guru penjas dalam meningkatan motivasi belajar olahraga siswa SD. Populasi penelitian ini adalah siswa SD di Kecamatan Japara Tahun Ajaran 2016/2017, sedangkan sampel penelitian sebanyak 30 siswa diambil secara acak (random sampling). Metode penelitian yang digunakan adalah metode deskriptif dengan alat pengumpul data adalah angket. Berdasarkan hasil penelitian, diperoleh hasil:1) gaya kepemimpinan guru penjas SD Kecamatan Japara Kabupaten Kuningan dari seluruh guru yang ada sebesar $65,73 \%$ meunjukan gaya otoriter, sebesar $75,33 \%$ menunjukan gaya demokratis, dan sebesar 72,67\% menunjukan gaya task oriented dalam meningkatkan motivasi belajar siswa; 2) motivasi siswa SD Kecamatan Japara Kabupaten Kuningan dalam melakukan olahraga terdorong oleh kebutuhan fisik sebesar $64,67 \%$, kebutuhan rasa aman sebesar 70,89\%, kebutuhan sosial sebesar 74,00\%, kebutuhan penghargaan sebesar 74,33\%, kebutuhan perwujudan diri (aktualisasi) sebesar $67,33 \%$; 3) hubungan gaya kepemimpinan guru penjas dengan motivasi siswa belajar olahraga menunjukan hubungan yang signifikan. Hasi perhitung koefisien korelasi (r) sebesar 0,63, bahwa nilai t-hitung $(4,292)$ lebih besar daripada t-tabel $(2,06)$ pada tingkat kepercayaan 0,975 dan $\mathrm{dk}=\mathrm{n}-2$. Selanjutnya diperoleh nilai koefisien determinasi sebesar $39,69 \%$. Artinya motivasi siswa dalam belajar olahraga didukung oleh komponen gaya kepemimpinan guru penjas sebesar 39,69\% dan 60,31\% didukung oleh komponen lain yang tidak di teliti. Berdasarkan hasil penelitian ini, penulis memberikan rekomendasi bahwa: guru harus menjadi pemimpin pendidikan yang disukasi, dipercaya, didengar bimbingannya, diteladani kepribadiannya dan dikenang sepanjang masa. Kepemimpinan guru untuk mempengaruhi para siswa supaya melakukan pembelajaran dengan baik adalah suatu keharusan. Oleh karenanya, guru prifesional hendaknya selalu berupaya untuk meningkatkan kepemimpinan dengan mengetahui tugastugas utama yang dilakukan pemimpin, fungsinya, dan keterampilan keterampilan apa yang harus dimiliki untuk menjadi pemimpin yang baik.
\end{abstract}

Kata Kunci : Gaya Kepemimpinan, Motivasi Belajar 


\section{PENDAHULUAN}

Proses pendidikan pada hakekatnya adalah usaha sadar yang dilakukan oleh orang dewasa (guru) terhadap orang yang belum dewasa (siswa) untuk mencapai kedewasaannya sesuai yang diharapkan. Hal ini sebagaimana yang dikemukakan Oemar Hamalik (2005:79) Bahwa "Pendidikan adalah suatu proses dalam rangka mempengaruhi siswa agar dapat menyesuaikan diri sebaik mungkin terhadap lingkungannya dan dengan demikian akan menimbulkan perubahan dalam dirinya yang memungkinkannya untuk berfungsi secara adekuat dalam kehidupan masyarakat.

Berdasarkan pendapat tersebut, guru merupakan orang yang diandalkan untuk melakukan proses pendidikan. Guru merupakan pemegang kendali yang membawa para anak didik untuk mencapai tujuannya. Untuk mencapai tujuan pendidikan dan pengajaran dengan baik, dalam arti dapat mencapai tujuan yang diharapkan secara optimal melalui proses yang efektif dan efisien, maka proses pendidiakn dan pengajaran tersebut harus dilaksanakan oleh tenaga guru yang propesional dalam arti guru tersebut dapat memenuhi tuntutan kebutuhan masyarakat.

Surya (2003:141) mendefinisikan guru yang propesional sebagai "guru yang memiliki keahlian, tanggungjawab, dan rasa kesejawatan”.Yang dimaksud dengan „memiliki keahlian"e adalah memiliki kompetensi yang layak untuk menjadi guru. Kompetensi di sini diartikan sebagai keseluruhan pengetahuan, sikap, dan keterampilan yang diperlukan oleh seseorang dalam kaitan dengan tugas seorang guru.Berkenaan dengan tanggungjawab, guru dalam menjalankan segala aktivitasnya terutama aktivitas profesionalnya haruslah disertai rasa tanggungjawab terhadap Allah SWT, bangsa dan negara, lembaga tempat mengabdi, organisasi profesi, dan kode etik jabatannya.Adapun yang dimaksud dengan rasa kesejawatan adalah satu perwujudan solidaritas kebersamaan guru sebagai sumber dinamika kebersamaan dalam mencapai tujuan bersama.

Berdasarkan uraian di atas, menunjukan bahwa tenaga pengajar jika akan melaksanakan tugasnya perlu memiliki ciri profesionalisasi keguruan berupa kompetensi guru yang menjadi tuntutan masyarakat sebagai pengguna jasa dari tenaga guru. Profesionalitas guru merupakan tuntutan yang harus dipenuhi oleh setiap guru.Hal ini merupakan satu cermin kualitas seorang guru. Semakin bagus profesionalitas seorang guru, maka semakin berkualitas proses belajar mengajar di sekolah tersebut. Pada sisi lainnya, bagaimana seorang guru mengarahkan dan membimbing para siswa ternyata mempunyai andil yang sangat besar keberhasilan siswa menyelesaikan tugas dan kewajibannya. Dengan kata lain, ada pengaruh gaya kepemimpinan guru dalam meningkatkan motivasi belajar siswa.

Pemimpin adalah sosok panutan yang secara sepakat dijadikan sebagai orang terdepan dari kegiatan hidup.Sosok ini mempunyai tugas dan kewajiban untuk memberikan perlindungan dan bantuan secara pribadi dan mengelola kegiatan agar dapat mencapai tujuan yang sudah diprogramkan.

Selanjutnya, seorang guru dalam melaksanakan tugasnya ternyata tidak hanya cukup terampil mengajar, memahami bidang studi yang akan diajarkannya, tetapi harus 
memiliki sikap yang tepat terhadap semua unsur yang terlibat dalam kegiatan proses pendidikan tersebut. Apabila salah satu syarat yang menjadi tuntutan guru tidak terpenuhi akan melaksanakan tugasnya, maka pelaksanaan proses pendidikan tersebut tidak akan berjalan dengan lancar.

\section{METODE PENELITIAN}

Pada penelitian ini penulis menggunakan metode deskriptif. Menurut Nazir (2005:54), metode deskriptif adalah suatu metode dalam meneliti status sekelompok manusia, suatu obyek, suatu set kondisi, suatu sistem pemikiran, ataupun suatu kelas peristiwa pada masa sekarang. Tujuan dari penelitian deskriptif ini adalah untuk membuat deskripsi, gambaran atau lukisan secara sistematis, faktual dan akurat mengenai fakta-fakta, sifat- sifat hubungan antarfenomena yang diselidiki. Dalam hal ini metode deskriptif digunakan agar diperoleh gambaran data hubungan gaya kepemimpinan guru penjas dalam meningkatkan motivasi belajar olahraga siswa SD di Kecamatan Japara. Instrumen pengambilan data pada penelitian ini dilakukan dengan teknik survey lapangan dan angket.

\section{HASIL}

Berdasarkan hasil analisis dan pengkajian, penulis mendapat data tentang gaya kepemimpinan guru penjas, motivasi belajar olahraga siswa SD Kecamatan Japara Kabupaten Kuningan, dan data hubungan gaya kepemimpinan guru penjas dengan motivasi belajar olahraga. Data -data tersebut dideskripsikan sebagai berikut.

\section{Gaya Kepemimpinan Guru Penjas}

a. Gaya kepemimpinan guru penjas SD Kecamatan Japara Kabupaten Kuningan dalam usaha meningkatkan motivasi belajar olahraga hanya $65,73 \%$ dari seluruh guru yang ada sebesar $65,73 \%$ menunjukan gaya otoriter dalam usaha meningkatkan motivasi belajar siswa. Artinya dengan gaya kepemimpinan otoriter guru , peserta didik hanya akan aktif kalau ada guru dan akalau guru tidak mengawasi maka semua aktifiotas menjadi menurun. Aktifitas proses belajar mengajar sangat tergantung pada guru dan menuntut sangat banyak perhatian guru.

b. Gaya kepemimpinan guru penjas SD Kecamatan Japara Kabupaten Kuningan dalam usaha meningkatkan motivasi belajar olahraga hanya 75,33\% dari seluruh guru yang ada sebesar $75,33 \%$ menunjukan gaya demokratis dalam usaha meningkatkan motivasi belajar siswa. Artinya gaya kepemimpinan guru yang demokratis lebih memungkinkan terbinannya sikap persahabatan guru dan siswa dengan adasar saling memahami dan asaling mempercayai. Sikap ini dapat membantu menciptakan iklim yang menguntungkan bagi terciptanya kondisi proses belajar mengajar yang optimal, peserta dididk akan belajar secara produktif baik apada saat diawasi maupun tanpa diawasi guru. 
c. Gaya kepemimpinan guru penjas SD Kecamatan Japara Kabupaten Kuningan dalam usaha meningkatkan motivasi belajar olahraga hanya $72,67 \%$ dari eluruh guru yang ada sebesar $72,67 \%$ menunjukan gaya task oriented dalam usaha meningkatkan motivasi belajar siswa. Artinya gaya kepemimpinan yang task oriented sangat produktif walaupun guru tidak ada di lapangan. Kalau guru ada siswa lebih banyak melakukan kegiatan yang sifatnya ingin diperhatikan oleh guru.dalam gaya kepemimpinan ini biasanya aktifitas siswa lebih produktif kalau gurunya tidak ada.

2. Motivasi belajar olaharaga siswa SD Kecamatan Japara Kabupaten Kuningan

a. Motivasi siswa SD Kecamatan Japara Kabupaten Kuningandalam melakukan olahraga terdorong oleh kebutuhan fisik sebesar 64,67\% . artinya motivasi siswa dalam melakukan olahraga 64,67\% terdorong oleh kebutuhan fisiologis, seperti : meningkatkan kebugaran jasmani, meningkatkan kapasitas fisik, pertumbuhan ideal, mengisi waktu luang, dan memperindah bentuk tubuh.

b. Motivasi siswa SD Kecamatan Japara Kabupaten Kuningandalam melakukan olahraga terdorong oleh kebutuhan rasa aman sebesar 70,89\%. Artinya motivasi siswa dalam melakukana olahraga 70,89\% terdorong oleh kebutuhan rasa aman, seperti : meningkatkan daya tahan tubuh terhadap penyakit, menghilangkan stres/ketegangan, dan memperoleh kenyamanan hidup.

c. Motivasi siswa SD Kecamatan Japara Kabupaten Kuningandalam melakukan olahraga terdorong oleh kebutuhan sosial sebesar 74,00\%. Artinya motivasi siswa dalam melakukan olahraga $74,00 \%$ terdorong oleh kebutuhan sosial, seperti : menjalin hubungan individu/kelompok, meningkatkan kerjasama antar individu, meningkatkan sportifitas dan mempererat persaudaraan/kekeluargaan.

d. Motivasi siswa SD Kecamatan Japara Kabupaten Kuningan dalam melakukan olahraga terdorong oleh kebutuhan penghargaan sebesar 74,33\% artinya motivasi siswa dalam melakukan olahraga 74,33\% terdorong oleh kebutuhan penghargaan seperti : meraih prestasi puncak, menjadi populer/terkenal, dan menjadi sebesar seorang yang berguna dan disegani melaui kegiatan olahraga.

e. Motivasi siswa SD Kecamatan Japara Kabupaten Kuningan dalam melakukan olahraga terdorong oleh kebutuhan perwujudan diri (aktualisasi) sebesar 67,33\% artinya motivasi siswa dalam melakukan olahraga $67,33 \%$ terdorong olah kebutuhan aktualisasi diri seperti : mengembangkan kapasitas fisik, mengembangkan kapasitas mental, memunculkan diri dan menampilkan seperti yang diidolakan.

3. Hubungan gaya kepemimpinan guru penjas dengan motivasi belajar olahraga

a. Hasil perhitungan koefisien korelasi ( $\mathrm{r}$ ) sebesar 0,63 dan selanjutnya untuk menguji signifikansi korelasi antara gaya kepemimpinan guru penjas ( $\mathrm{X}$ ) dengan motivasi siswa belajar olahraga ( $\mathrm{Y}$ ) dilakukan pengujian dengan uji t. 
Hasilnya membuktikan bahwa nilai t-hitung $(4,292)$ lebih besar dari pada t-tabel $(2,06)$ pada tingkat kepercayaan $0,975 \mathrm{dan} d \mathrm{k}=\mathrm{n}-2$. hal ini menunjukan bahwa hubungan gaya kepemimpinan guru penjas $(\mathrm{X})$ dengan motivasi siswa belajar olahraga (Y) menunjukan hubungan yang signifikan.

b. Mengenai hubungan fungsional antara besarnya dukungan dari variable-variable tersebut penulis hitung dengan menggunakan koefisien determinasi $r^{2} \times 100 \%$. yaitu $(0,63)^{2} \times 100 \%$ diperoleh nilai koefisien determinasi sebesar 39,69\% terhadap motivasi siwa dalam belajar olahraga. Artinya motivasi siswa dalam belajar olahraga didukung oleh komponen gaya kepemimpinan guru penjas sebesar 39,69\% dan 60,31\% didukung oleh komponen lain yang tidak diteliti.

\section{PEMBAHASAN}

Berdasarkan hasil pengolahan, penulis dapat menyimpulkan hasil penelitian sebagai berikut.

a. Gaya kepemimpinan guru dalam pelaksanaan proses belajar mengajar bidang studi penjas di SD Kecamatan Japara Kabupaten Kuningan menggunakan gaya otoriter sebanyak $65,73 \%$, gaya demokratis sebesar $75,33 \%$, dan task oriented sebesar $72,67 \%$.

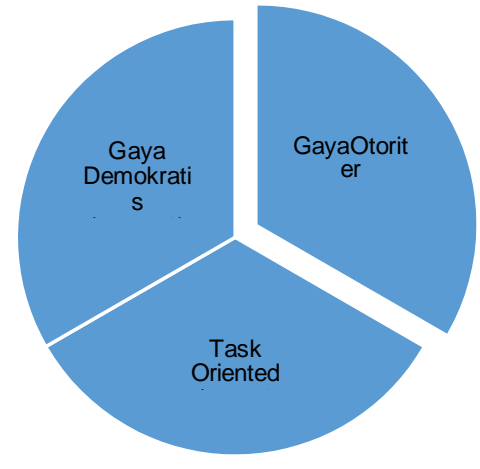

b. Motivasi belajar pada siswa SD sewilayah Kecamatan Japara dalam melakukan olahraga terdorong oleh kebutuhan meningkatkan kebugaran jasmani sebesar 64,67\%, kebutuhan rasa aman sebesar 70,89\%, dan kebutuhan sosial sebesar 74,00\%.

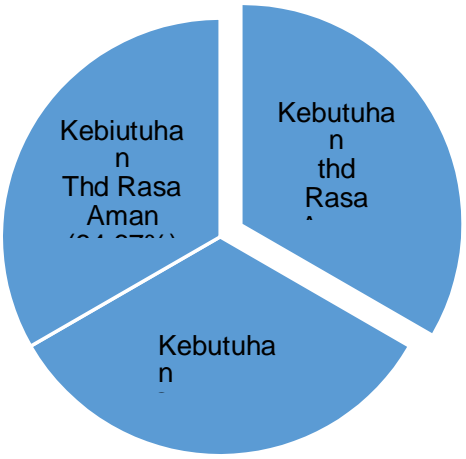


c. Terdapat hubungan yang signifikan $(\mathrm{r}=0,63)$ antara gaya kepemimpinan guru penjas dengan motivasi belajar siswa SD Kecamatan Japara Kabupaten Kuningan.

\section{KESIMPULAN}

Penelitian ini telah menunjukan bahwa, Semakin bagus profesionalitas seorang guru, maka semakin berkualitas proses belajar mengajar di sekolah tersebut. Pada sisi lainnya, bagaimana seorang guru mengarahkan dan membimbing para siswa ternyata mempunyai andil yang sangat besar keberhasilan siswa menyelesaikan tugas dan kewajibannya. Dengan kata lain, ada pengaruh gaya kepemimpinan guru dalam meningkatkan motivasi belajar siswa. 


\section{REFERENSI}

Arikunto, Suharsimi.2006.Manajemen Penelitian. Jakarta:Rineka Cipta. De Porter, B. Dan Hernacki, M.2003.Quantum Learning:Membiasakan Belajar Nyaman dan Menyenangkan.

Bandung:Penerbit Kaifa.

Fandi dan Anastasia Diana.2003.Total Quality Management (TQM).Yogyakarta: Andi Gerungan,

W.A.2002.Psikologi Sosial.Bandung:Refika Aditama.

Gunarsa, Singgih D. Dkk.1989.Psikologi Olahraga.Jakarta:PT. BPK Gunung Mulia

Harsono.1988.Coaching dan Aspek-aspek Psikologis dalam Coaching.Jakarta:Tambak

Kusumah Mulyasa.2005.Manajemen Berbasis Sekolah.Bandung:Remaja Rosdakarya

Muchtar, S.2001.Pendidikan dan Masalah Sosial Budaya.Bandung:Gelar Pustaka Mandiri. Hamalik, Oemar.2005.Proses Belajar Mengajar.Jakarta:PT Bumi Aksara.

Sardiman.2006.Interaksi dan Motivasi Belajar Mengajar.Jakarta:PT Raja Grafindo Persada.

Setyobroto.2001.Kepemimpinan dalam Managemen.Jakarta:PT Rajawali Pers.

Sudjana.1988.Statistik.Bandung:Tarsito.

Sugandha, Dann.1986.Kepemimpinan Di dalam Administrasi.Bandung:Sinar Baru.

Sugiyono.2012.Metode Penelitian Kuantitatif, Kualitatif dan R\&D.Bandung:Alfabeta Soekanto,

S.2003.Sosiologi:Suatu Pengantar.Jakarta:PT Raja Grafindo.

Surakhmad, Winarno.1990.Pengantar Penelitian Ilmiah, Dasar, Metode,dan

Teknik.Bandung:Tarsito.

Surya, M.2003.Psikologi Pembelajaran dan Pengajaran.Bandung:Yayasan Bhakti Winaya. Thoha, Miftah.1983.Kepemimpinan dalam Manajeman.Jakarta:Rajawali Pers Tjiptono 